\title{
FINAL ACCOUNT BUDGET IN ESTABLISHING BUDGET RIGHT, ASSESSMENT AND RECOMMENDATIONS: THE CASE OF TURKEY
}

\author{
Serdar DUMLUPINAR ${ }^{1}$
}

\begin{abstract}
States need income to provide for some of their needs and, based on sovereignty, direct their economic decisions on the individuals who make up the society. The budget right has developed as measures to prevent the inflexibility of these economic decisions. From this point, the right to budget implies limiting the incomes and expenditures of the states by members of the society and the approval and control of these limitations every year. There are many tools to implement the budget right. The final account budget is one of these tools. The final account budget aims to determine whether the competence given in the previous year budget is used within the limits set by the legislative body. The aim of this study is to determine the location and impoprtance of the final account budget in establishing the budget right and in particular Turkey's application is to identify aspects that hinder the right budget and to propose solutions to these difficulties. In the study, the final account budget; aspects that hinder budget right, have been detected in particular Turkey and have been mentioned in solutions for them. The aspects created the fault, mainly; commission structure, meeting schedule, creating awareness process and political applications. The solutions of these problems, which create problems, were examined and expressed in the study. ccordingly, for the solution; the establishment of a new final account commission, changing the timetable for the final account budget, the development of information tools for raising public awareness, and the suggestions for change in the electoral system and amendments to the control at a constitutional level were discussed in the study.
\end{abstract}

Keywords: Budget Right, Final Account Budget, Democracy

JEL Code: H60, H61, H83.

\section{Introduction}

The budget right can be used through many tools. Control of the final account budget is one of these tools. The final account budget refers to the legislative control of governments over the past year's budgets. The final account budget, how the competence of the legislature to authorize to exucutive body, helps to examine the data obtained through realizations.The fact that the final account budget contains final results regarding the realization of the applications is of great importance in the use of the budget right, as well as the right to approve the budgets, as well as the control of how this authority is used.The purpose of this study is to express the role of the final account budget in establishing the budget right and to examine the current structure in our country and to identify the aspects that disrupt the budget right and to offer solution suggestions for this.

The limitation of the study is to limit the establishment of the budget right with the final account budget.Apart from the problems and solutions mentioned in this study, there are many problems and solutions to improve the budget right. However, they are outside the subject. The study also was limited to our country due to contains in special fields application of Turkey.

1 Res. Asst., Siirt University Public Finance Department, serdardumlupinar@hotmail.com 
The study consists of 2 sections except the introduction and conclusion sections. In the first chapter, the concept of budget right will be examined by explaining the relation between budget right and democracy. In the second part, the final account budget and budget right relationship will be expressed and the final account budget implementation in our country will be examined. In addition, the aspects of the application which disrupt the budget right and suggestions for solutions will be discussed in this section.

\section{The Concept of Budget Right and Content}

\subsection{The Relationship Between Budget Right and Democracy}

Historically, policy and economy studies have been very closely related. Economy influenced to policy decisions at the same time policy decisions influenced to economy decisions (Holcombe, 1996: 18). Accordingly, it should be stated that financial institutions and systems are born and developed in parallel with political organizations and systems. Historical experience means that the centralization of the entire financial system in its country, in order for a state to have full sovereignty and authority, The fact that all of his incomes were to enter his own treasury and all his expenses were to be paid by him again (Feyzioğlu, 1984: 14). The budget right has political characteristics because of the fact that the budgets to be implemented include characteristics that affect the social life and force the society on some issues. Therefore, the use of the budget right has become an unseperable part of the sovereignty right in every period of history (Özbilen, 2013: 16).

\subsection{The Concept of Budget Right}

The society that accommodates many different individual requests reaches a consensus on the public space to be governed by elections (Hırsch, 1970: 18). The budgets brought by the consensus resulting from the elections have a quality that reflects the needs of the society in this respect (Lynch, 1985: 6).

Sayar (1964), has defined the budget right as budget, the amount of the expenses to be made with the revenues obtained from tax and other sources as the right of determination and approval.According to Batirel (1990: 5) budget right is the right to determine the amount and composition of public expenditure and revenues.Gürsoy (1980: 56) expressed the budget right, where and to what extent the state should spend money, and what kind of obligations will be put as a result of these expenditures, to decide on behalf of the nation or the nation, and the status of authorized representative assemblies.

The budget right consists of 3 elements in the light of these definitions. These are the problem of determining the general needs in the society and making them subject to public services, the kind of income to be used in making social expenditures and their collection and decision power, how and how to use them (Özbilen, 2013: 16). 


\section{Final Account Budget}

\subsection{Final Account Budget as a Function of Budget Right}

In terms of the exercise of the right to budget, legisture authorizes to executive body to obtain public revenues and make public expenditures, naturally requires the auditingof the exercise of these powers (Bağlı, 2014: 51). In terms of the use of the right to budget, not examining how the authority given by the budget law is used by the legislative body will cause a contradiction with the logic of law.For this reason, the legislature, which approves the budget, also makes use of the budget right by checking the results. (Ayanoğlu, 2016: 146). A right only carry value when it used. The final account budget also represents the use of budget right through the control of the authority granted to the executive body by the legislature (Gürsoy, 1980: 444).

\subsection{Structure and Functioning of the Final Account Budget in Turkey}

\subsubsection{Sides to Final Account Budget}

The structures that are effective in the process of preparing and enacting the final account budget are the President, the Ministry of Treasury and Finance, the Court of Accounts, the Planning and Budget Commission and the Assembly General Assembly.

\subsubsection{Legal Basis of Final Account Budget, Preparation and Discussion}

The final account budget is applied together with mainly Constitution and the Law No. 5018. Arrangements, tables specified in Law No. 5018 and regulations about other tables prepared by Ministry of Finance, has been determined with "Regulation on Principles and Procedures Regarding the Regulation of Final Accounts of Public Administrations", published in the Official Gazette dated 26.04.2006 and numbered 26150 published by the Ministry of Finance.

\subsubsection{Acceptance and Denial of Final Account Budget}

The budget process includes a two-way legislative activity. The next year's budget is discussed and approved, and the final account budget is discussed and resolved.It is known that both budgets are limited by the same date range in terms of the length of consultation and approval in the parliament.Each legislative process includes the option of rejection as well as approval.

\subsection{Major Aspects and Solution Suggestions Hindering Budget Right Sources From Final Account Budget in Turkey}

In the light of the information related to the application, if the issue is needed, the weakening of the legislative control over the final account budget within the existing system;

- Inadequacy of the existing commission structure,

- Interview schedule is inappropriate for auditing

- Inability to obtain information channels,

- Challenges brought by the electoral systemcan be expressed as. 
On the other hand, if needs recommendations gathered;

- A new final account commission should be established. A commission structure in which the chairman is elected from the opposition and the interviews open to the media is important in terms of final auditing.

- The meeting schedule is very important for the subject. A more appropriate timetable should be determined and final account budget negotiations should be separated from next year's budget negotiations and should be taken forward.Thus, in the next year's budget negotiations, it will be possible for legislative members to benefit from past year practices.Also the tight schedule, therefore, remains in the background of the final account will be eliminated and also will increase awareness of the members of the legisture, the government and the society. Thus, the issue of accountability will be ensured by controlling the final account budget.

- Awareness should be increased in the context of the right to budget by operating information retrieval channels. In order to ensure that the commission meetings on this subject reach the public; open meetings, the existence of a report containing the problems identified in the final audits, and the traceability of such reports, where the commission deems necessary, it should be ensured that the top executives of the expenses can be called to the meetings.The implementation of the follow-up reports and the practices of the executive branch on the results contained in these reports, before the new year budget process, and to the public through the media, will make a significant contribution to the functioning of the budget right.

- Narrowed selection system method; will lead to the elimination of the parlieamentarians from the party pressures, the legitimacy of the policies they implement, and the freedom of movement. In addition, the method of interpillation andsubjecting the appointment of ministers to the parliamentary approval will also serve as an important auditing function.

\section{Conclusion}

The final account budget is a structure that expresses the implementation of the governments' past year budgets. While the next year's budget expresses forecasts, the final account budget represents the realizations. For this reason, the legislature's control of the executive body through the final account budget and the approval of the final account budget as a result of these audits means that in a sense the government approved its past practices. In this respect, audits on the final account budget are an important tool for auditing the implemented applications.

Final accounts are submitted to the General Assembly after being discussed together with the next year's budget in the plan and budget committee and are approved and discussed together in the General Assembly.The problems we face here are that the final accounts do not have a separate final account commission to allow for an adequate review, and they are less important than the next year's budgets in terms of the negotiating schedule.In this respect, a discussion schedule should be organized and a separate final commission commission should be established. Together with the legislative and executive members, it is seen that the people lack the necessary sources of information on the final account. Interviews should be provided to the public through open meetings through media, and the follow-up of the applications in the following years should be ensured on the problems mentioned in the reports created as a result of the final audits. 
Thus, awareness of all stakeholders will be increased. Party pressure and the dominance of party policies on legislators are an obstacle to their ease of movement. This situation in the process of final auditing, causes the legislators who are restricted to freedom of movement to remain inadequate in defending the budget right.The narrowed zone selection system for this case would be a good practice. Thus, the pressure on the legislators will be alleviated, and the real owner of the budget right will not feel responsible for the people, not the party administration.Finally, the interpillation method and the approval of the appointments of ministers by the parliament will also increase the operability of the audit and, hence, the budget right.

\section{References}

Ayanoğlu, A. (2016). Türk Bütçe Sistemi ve Bütçe Denetimi Kavram-Mevzuat-Uygulama, Ankara: Seçkin Yayıncılık.

Bağlı, M. S. (2012)."Teorik ve Tarihsel Açıdan Bütçe Hakkı”, Yasama Dergisi, S:20, ss. 39-77.

Bağlı, M. S. (2014). “TBMM’nin Bütçe Hakkını Kullanım Durumu: 5018 Sayılı Kanun Sonrası Bütçe Hakkı Kullanımında Etkinlik Düzeyinin Ölçümü”, Ankara Üniversitesi Sosyal Bilimler Enstitüsü(Yayınlanmamış Doktora Tezi), Ankara.

Batırel, Ö. F. (1990).Kamu Bütçesi, İstanbul: Marmara Üniversitesi Nihad Sayar Yayın ve Yardım Vakfi.

Feyzioğlu, B. N. (1984).Nazari, Tatbiki, Mukayeseli Bütçe, İstanbul: Filiz Kitabevi.

Gürsoy, B. (1980).Kamusal Maliye ikinci Cilt Bütçe, Ankara: Ankara Üniversitesi Siyasal Bilgiler Fakültesi Yayınları.

Hırsch, W. Z. (1970). The Economics of State and Local Government, Newyork: McGraw-Hill Book Company.

Holcombe, R. G. (1996). Public Finance Government Revenues and Expenditures in The United States Economy, Minneapolis: West Publishing Company.

Özbilen, Ş. (2013). Devlet Bütçesi, Ankara: Gazi Kitabevi.

Sayar, N. S. (1964).Amme Maliyesi: Ikinci Cilt Bütçe Prensipleri ve Tatbikat, İstanbul: İtisadi ve Ticari İlimler Akademisi Yayınları. 